\title{
Photoinduced Rearrangement Reaction of 2-(Pentamethyldisilanyloxymethyl) phenylpentamethyldisilane ${ }^{\dagger}$
}

\author{
Seung Ki Park* and Su Yeon Gong \\ Department of Chemistry, College of Natural Sciences, The University of Suwon, Suwon 445-743, Korea \\ *E-mail: skpark@suwon.ac.kr \\ Received October 19, 2009, Accepted December 23, 2009
}

Key Words: 2-(Pentamethyldisilanyloxymethyl)phenylpentamethyldisilane, Disilane

It is well known that disilane molecules having a siliconsilicon $\sigma$ bond show unique properties in the photochemical ${ }^{1-4}$ and thermal reactions ${ }^{5}$ and in the transition metal catalyzed reactions ${ }^{6-14}$ since the first reports on the unusual electronic spectra of aryldisilanes by Sakurai et al., ${ }^{15}$ Gilman et al. ${ }^{16}$ and Hague et al. ${ }^{17}$ in 1964.

In the context of our interest on the synthesis of silicon containing heterocyclic compounds by the photoreactions of ortho-substituted arylalkynyldisilanes ${ }^{18-29}$ and aryldisilanes, ${ }^{30,31}$ we have very recently reported on the photoreaction of (2-pentamethyldisilanyloxy)phenylpentamethyldisilane ${ }^{32}$ in the presence of methanol or acetone affording a novel intramolecular photoproduct via silene intermediate. In light of a reactivity of benzyl position, we have now extended our research on the compound 2-(pentamethyldisilanyloxymethyl)phenylpentamethyldisilane 1 since novel photoproducts from the intramolecular reaction between two ortho-pentamethyldisilanyl groups are expected. In this article, we would like to report the detailed photochemical study of 2-(pentamethyldisilanyloxymethyl)phenylpentamethyldisilane $\mathbf{1}$.

The starting 2-(pentamethyldisilanyloxymethyl)phenylpentamethyldisilane 1 was prepared by the reaction of chloropentamethyldisilane with 2-(pentamethyldisilanyloxymethyl)- phenylmagnesium iodide in tetrahydrofuran (Scheme 1).

To investigate whether or not the pentamethyldisilanyloxymethyl group as ortho substituent in $\mathbf{1}$ reacts intramolecularly with the photoexcited state of $\mathbf{1}$, the photolysis of $\mathbf{1}$ was performed.

Irradiation of 1 in deaerated methanol with $254 \mathrm{~nm} \mathrm{UV} \mathrm{light}$ afforded a compound $\mathbf{3}$ ( $80 \%$ yield) along with some decomposition products of unknown structure as shown in Scheme 2, when $98 \%$ of 1 was photolyzed. The formation of a photoproduct 3 can best be explained in terms of the nucleophilic attack at $\alpha$ silicon atom of pentamethyldisilanyloxymethyl group in the photoexcited state of $\mathbf{1}$ by methanol (path d). Indeed, it is well known that the photolysis of substituted phenylpentamethyldisilanes has four reaction pathways: ${ }^{33}$ (path a) formation of a silene compound and a trimethylsilane, ${ }^{34}$ (path b) formation of a silatriene compound arising from 1,3-shift of trimethylsilyl radical, which is formed via homolytic cleavage of siliconsilicon bond to the $\mathrm{C}_{6}$ position of benzene ring, ${ }^{35-46}$ (path c) formation of a trimethylsilyl compound via elimination of a silylene, ${ }^{47}$ (path d) formation of a direct solvolysis compound accompanied by the formation of trimethylalkoxysilane and trimethylsilane. $^{48,49}$ In relation to the photoreactions of the compounds with bis(disilanyl) group similar to the compound

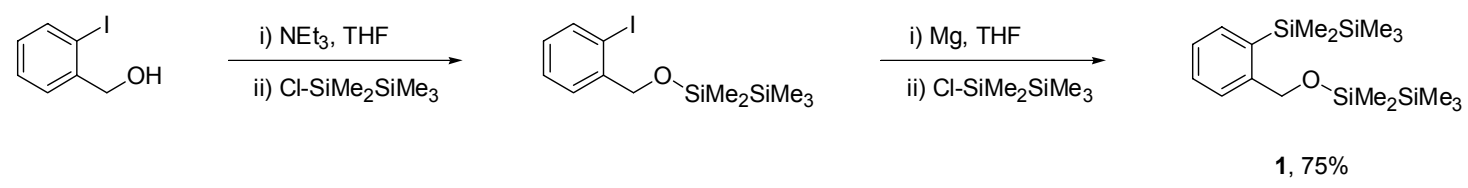

Scheme 1

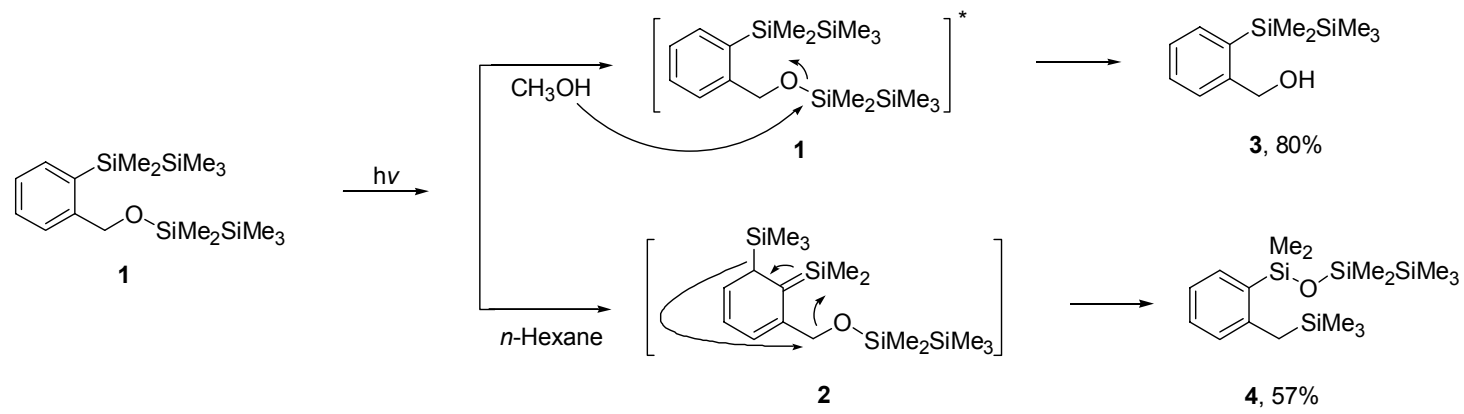

Scheme 2 
<smiles>CCOCc1ccccc1COC</smiles>

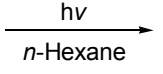

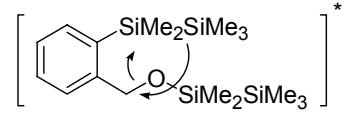

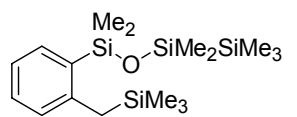

4, $57 \%$

Scheme 3

1, Ishikawa et al. ${ }^{50}$ found the photolysis of 1,2-, 1,3-, and 1,4bis(disilanyl)benzene in the presence of isobutene gave 2-(isobutyldimethylsilyl)-1-(pentamethyldisilanyl)-3-(trimethylsilyl)benzene, 1,1-dimethyl-6-[1,1-dimethyl-2-(trimethylsilyl)ethyl]-4-(pentamethyldisilanyl)silepin, and 4-(isobutyldimethylsilyl)-1-(pentamethyldisilanyl)-5-(trimethylsilyl)benzene via the photochemically generated rearranged silatriene intermediate (path b). In the case of the photolysis of 1,4-bis(pentamethyldisilanyl)naphthalene $\mathrm{e}^{51}$ in the presence of methanol, 4-(dimethylsilyl)-1-(pentamethyldisilanyl)-5-(trimethylsilyl) naphthalene via the radical scission of a silicon-silicon bond of the photoexcited starting compound and 6-(methoxydimethylsilyl)-6,7-bis(trimethylsilyl)-5,8-(dimethylsilano)-5,6,7, 8-tetrahydronaphthalene via a silatriene intermediate (path b) were obtained. And, in the case of the photoreaction of 2(pentamethyldisilanyloxy)phenylpentamethyldisilane ${ }^{32}$ in the presence of methanol, the photoproducts via silatriene intermediate (path b) and direct solvolysis (path d) were obtained.

Irradiation of 1 in deaerated $n$-hexane with $254 \mathrm{~nm}$ UV light afforded a novel rearranged photoproduct 4 (57\% yield) along with some decomposition products of unknown structure as shown in Scheme 2, when $85 \%$ of 1 was photolyzed. The formation of a novel photoproduct 4 can best be explained in terms of the initial formation of silatriene intermediate $\mathbf{2}$ (path b) arising from 1,3-migration of trimethylsilyl radical, which is formed via the homolytic cleavage of silicon-silicon bond of pentamethyldisilanyl group in the photoexcited state of $\mathbf{1}$ to the $\mathrm{C}_{6}$ position of benzene ring. The intramolecular oxygen attack of pentamethyldisilanyloxymethyl group in $\mathbf{2}$ to silicon atom in silene moiety of intermediate $\mathbf{2}$ accompanied by an aromatization, 1,4-trimethylsilyl shift and the elimination of pentamethyldisilanyloxy group gives the compound 4 . In relation to the formation of the photoproduct 4 , our laboratory reported the photolysis of (2-acetoxymethylphenyl)pentamethyldisilane $^{52}$ in the presence of methanol gave the rearranged photoproduct via the intermolecular reaction of methanol to silicon atom in silatriene moiety of reaction intermediate (path b) accompanied by a aromatization, 1,4-trimethylsilyl shift similar to the formation of the compound 4 . One might consider the possibility that the photoproduct $\mathbf{4}$ could be produced by a concerted process involving the intramolecular oxygen attack of the pentamethyldisilanyloxy group to $\alpha$ silicon atom of the pentamethyldisilanyl group in the photoexcited state of 1 accompanied by the attack of trimethylsilyl group to a benzyl position of the photoexcited state of $\mathbf{1}$ as shown in Scheme 3. However, no product derived from the intramolecular reaction of other possible intermediates except silatriene intermediate with orthosubstituted group was detected in the photolysis of aryldisilanes $^{30-32,52}$ and the reaction mechanism as shown in Scheme 3 are not reasonable. The structure of the photoproduct 4 was

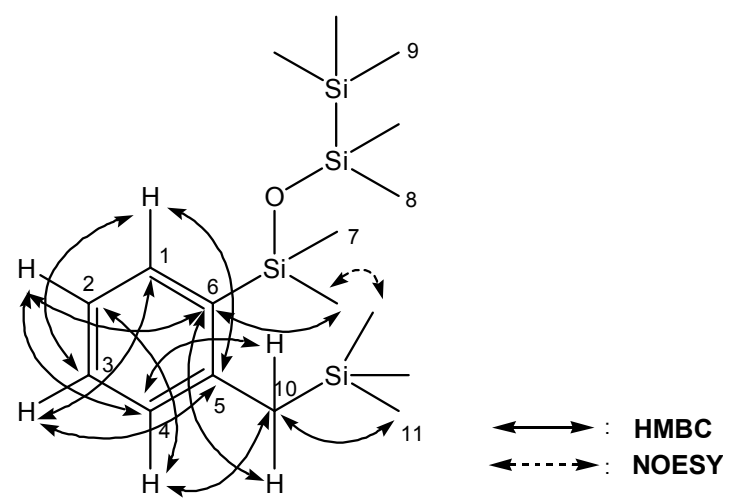

Figure 1. Important correlations observed in HMBC and NOESY spectra of photoproduct 4 .

also determined by various physical methods, such as ${ }^{1} \mathrm{H}$ NMR, ${ }^{13} \mathrm{C}$ NMR, 2D NMR $\left({ }^{1} \mathrm{H}-{ }^{1} \mathrm{H},{ }^{1} \mathrm{H}^{13} \mathrm{C}\right.$ COSY, HMBC, and NOESY), UV, FT-IR, and high resolution mass spectrometry. The ${ }^{1} \mathrm{H}-{ }^{1} \mathrm{H}$ and ${ }^{1} \mathrm{H}-{ }^{13} \mathrm{C}$ correlation spectroscopy (COSY) spectra of 4 were carried out to identify the protons directly attached to the individual carbons. According to the correlated peaks in 4, we have been able to identify the pairs of carbons and directly bonded protons as shown in Table 1. From the HMBC spectrum of $\mathbf{4}$, the structure skeleton of $\mathbf{4}$ was determined. The connectivity of the carbon $\mathrm{C}(6)$ to the dimethylsilyl group in $\mathbf{4}$ was established by the presence of the cross-peaks due to the vicinal coupling between the quaternary carbon $\mathrm{C}(6)$ and the protons of $\mathrm{C}(7)$ in 4 . The presence of the cross-peaks due to the vicinal coupling between the carbon $\mathrm{C}(10)$ and the proton of $\mathrm{C}(4)$, and the carbon $\mathrm{C}(10)$ and the protons of $\mathrm{C}(11)$ in 4 showed the connectivity of the carbon $\mathrm{C}(5)$ to the trimethylsilylmethyl group in 4. In the same manner, the presence of the cross-peaks due to the vicinal coupling between the quaternary carbon $\mathrm{C}(6)$ and the protons of $\mathrm{C}(10)$ in $\mathbf{4}$ also showed the connectivity of the carbon $\mathrm{C}(5)$ to the trimethylsilylmethyl group in 4 . From the presence of the cross-peaks between the protons of $\mathrm{C}(7)$ and the protons of $\mathrm{C}(11)$ which is showed in a nuclear overhauser and exchange spectroscopy (NOESY) of 4 , it was determined that these protons are located on the same side of the molecule. Thus, the skeletal structure of $\mathbf{4}$ was unambiguously established as shown in Figure 1.

In conclusion, the photolysis of $\mathbf{1}$ in methanol provided a compound $\mathbf{3}$. The formation of $\mathbf{3}$ can be explained in terms of $\alpha$ silicon atom attack of methanol to pentamethyldisilanyloxymethyl group in the photoexcited state of $\mathbf{1}$. Irradiation of 1 in $n$-hexane gave a novel rearranged photoproduct 4 . The formation of $\mathbf{4}$ in $n$-hexane solvent was probably explained by the intramolecular oxygen attack to silicon atom in silatriene 
Table 1. ${ }^{1} \mathrm{H}$ NMR $(500 \mathrm{MHz}),{ }^{13} \mathrm{C}$ NMR $(125 \mathrm{MHz})$, and $\mathrm{HMBC}$ data for photoproduct 4 in $\mathrm{CDCl}_{3}{ }^{a}$

\begin{tabular}{|c|c|c|c|c|c|c|c|}
\hline Position & $\delta_{\mathrm{C}}(\mathrm{ppm})$ & $\mathbf{M}^{b}$ & $\delta_{\mathrm{H}}(\mathrm{ppm})$ & $\mathrm{I}^{c}$ & $\mathrm{M}^{d}$ & $J_{\mathrm{H}-\mathrm{H}}(\mathrm{Hz})$ & $\mathrm{HMBC}^{e}$ \\
\hline 1 & 134.9 & $\mathrm{~d}$ & 7.51 & $1 \mathrm{H}$ & $\mathrm{dd}$ & $7.5\left(J_{1 \mathrm{H}-2 \mathrm{H}}\right), 1.5\left(J_{1 \mathrm{H}-3 \mathrm{H}}\right)$ & H3 \\
\hline 2 & 123.6 & $\mathrm{~d}$ & 7.10 & $1 \mathrm{H}$ & $\mathrm{d}$ & $7.5\left(J_{2 \mathrm{H}-1 \mathrm{H}}\right)$ & $\mathrm{H} 4$ \\
\hline 3 & 129.4 & d & 7.26 & $1 \mathrm{H}$ & $\mathrm{td}$ & $7.5\left(J_{3 \mathrm{H}-2 \mathrm{H}, 4 \mathrm{H}}\right), 1.5\left(J_{3 \mathrm{H}-1 \mathrm{H}}\right)$ & $\mathrm{H} 1$ \\
\hline 4 & 128.5 & $\mathrm{~d}$ & 7.06 & $1 \mathrm{H}$ & $\mathrm{d}$ & $7.5\left(J_{4 \mathrm{H}-3 \mathrm{H}}\right)$ & $\mathrm{H} 2, \mathrm{H} 10$ \\
\hline 5 & 146.4 & s & & & & & $\mathrm{H} 1, \mathrm{H} 3$ \\
\hline 6 & 137.3 & $\mathrm{~s}$ & & & & & $\mathrm{H} 2, \mathrm{H} 4, \mathrm{H} 7, \mathrm{H} 10$ \\
\hline 7 & 3.41 & q & 0.39 & $3 \mathrm{H}$ & $\mathrm{s}$ & & \\
\hline 8 & 2.29 & $\mathrm{q}$ & 0.24 & $3 \mathrm{H}$ & $\mathrm{s}$ & & \\
\hline 9 & -2.02 & $\mathrm{q}$ & 0.09 & $3 \mathrm{H}$ & $\mathrm{s}$ & & \\
\hline 10 & 26.7 & $\mathrm{t}$ & 2.35 & $2 \mathrm{H}$ & $\mathrm{s}$ & & H4, H11 \\
\hline 11 & -0.59 & $\mathrm{q}$ & 0.05 & $3 \mathrm{H}$ & $\mathrm{s}$ & & $\mathrm{H} 10$ \\
\hline
\end{tabular}

${ }^{a}$ All these assignments were confirmed by ${ }^{1} \mathrm{H}-{ }^{1} \mathrm{H}$ and ${ }^{1} \mathrm{H}-{ }^{13} \mathrm{C}$ COSY and NOESY, HMBC spectra. ${ }^{b}$ Multiplicities were determined by DEPT spectrum. ${ }^{c}$ Integrated intensity. ${ }^{d}$ Multiplicities. ${ }^{e}$ Protons correlated to carbon resonances in ${ }^{13} \mathrm{C}$ column.

moiety, aromatization, 1,4-trimethylsilyl shift, and the elimination of pentamethyldisilanyloxy group.

\section{Experimental}

General methods. All reactions were carried out under an atmosphere of dry nitrogen. ${ }^{1} \mathrm{H}$ and ${ }^{13} \mathrm{C}$ NMR spectra were recorded on Bruker AM-300 and Bruker AC-200 spectrometers with chemical shifts being referenced against TMS as an internal standard or the signal of the solvent $\mathrm{CDCl}_{3}$. UV absorption spectra were recorded on a Hewlett-Packard 8453 spectrophotometer. Mass spectra were determined at $70 \mathrm{eV}$ with a Hewlett-Packard 5985A GC-MS by the electron impact (EI) method. FT-IR spectra were recorded on a Bomem MB-100 spectrometer in $\mathrm{KBr}$ pellets and $\mathrm{NaCl}$ cell. High-performance liquid chromatography was performed on a Waters Associates Model 244 liquid chromatograph (Mildford, MA) equipped with a Model 6000A solvent delivery system, Model 440 UV absorbance detector fixed at $254 \mathrm{~nm}$, and Model U6K universal injector. Lichrosorb SI-60 column was used for preparative analyses. Thin layer chromatography (TLC) was performed on Sigma-Aldrich pre-coated silica gel $\mathrm{F}_{254}$ aluminum foils. Purification of the reaction products was carried out by flash column chromatography using a glass column dry packed with silica gel (230 - 400 mesh ASTM).

Materials. Tetrahydrofuran was refluxed over sodium benzophenone and distilled under nitrogen. Methanol (HPLC grade) and $n$-hexane (HPLC grade) were distilled from $\mathrm{CaH}_{2}$ before use. $\mathrm{Et}_{3} \mathrm{~N}$ was distilled from $\mathrm{CaH}_{2}$ and stored over $\mathrm{KOH}$ pellets. Solvents of reagent grade for chromatography were used without further purification. Spectroscopic grade solvents were used for HPLC and UV absorption spectra.

Synthesis of 2-(pentamethyldisilanyloxymethyl)phenylpentamethyldisilane 1 . Triethylamine $(0.71 \mathrm{~mL}, 5.12 \mathrm{mmol})$ was added to a solution of 2-iodobenzyl alcohol ( $1 \mathrm{~g}, 4.27 \mathrm{mmol})$ in tetrahydrofuran $(30 \mathrm{~mL})$ at room temperature under nitrogen atmosphere. Chloropentamethyldisilane ( $1 \mathrm{~mL}, 5.12 \mathrm{mmol})$ was added dropwisely to the resulting solution and the mixture was refluxed for $3 \mathrm{~h}$. The reaction mixture was filtered with celite, and concentrated in vacuo. To this reaction residue, THF (30
$\mathrm{mL}$ ) was added. This resulting reaction solution was added to $\mathrm{Mg}(0.31 \mathrm{~g}, 12.8 \mathrm{mmol})$ at room temperature under nitrogen atmosphere. Chloropentamethyldisilane (1 mL, $5.12 \mathrm{mmol})$ was added dropwisely to the resulting solution and the mixture was refluxed for $0.5 \mathrm{~h}$. The reaction mixture was filtered with celite, and concentrated in vacuo. Water $(30 \mathrm{~mL})$ was added to the solution and extracted with ethyl acetate $(3 \times 15 \mathrm{~mL})$. The combined ethyl acetate solution was washed with water $(20$ $\mathrm{mL})$, brine $(20 \mathrm{~mL})$ and dried $\left(\mathrm{MgSO}_{4}\right)$. The solvent was evaporated in vacuo to give the crude product. Flash column chromatography with $n$-hexane/ethyl acetate $(50 / 1, \mathrm{v} / \mathrm{v})$ as an eluent gave 1 (1.18 g, 75\% yield) as a colorless oil; ${ }^{1} \mathrm{H}$ NMR $\left(\mathrm{CDCl}_{3}, 300 \mathrm{MHz}\right) \delta_{\mathrm{H}} 0.082(9 \mathrm{H}, \mathrm{s}), 0.14(9 \mathrm{H}, \mathrm{s}), 0.29(6 \mathrm{H}, \mathrm{s})$, $0.39(6 \mathrm{H}, \mathrm{s}), 4.71(2 \mathrm{H}, \mathrm{s}), 7.23(1 \mathrm{H}, \mathrm{d}, J=7.2 \mathrm{~Hz}), 7.37(1 \mathrm{H}, \mathrm{t}$, $J=7.8 \mathrm{~Hz}), 7.42(1 \mathrm{H}, \mathrm{d}, J=7.2 \mathrm{~Hz}), 7.52(1 \mathrm{H}, \mathrm{d}, J=7.8 \mathrm{~Hz}) ;{ }^{13} \mathrm{C}$ $\mathrm{NMR}\left(\mathrm{CDCl}_{3}, 75 \mathrm{MHz}\right) \delta_{\mathrm{C}}-2.09,-1.85,-1.59,-0.58,65.8$, $126.2,126.4,128.9,134.5,135.8,146.7$; UV $\left(\mathrm{CH}_{2} \mathrm{Cl}_{2}\right) \lambda_{\max }$ $236 \mathrm{~nm}$; FT-IR (NaCl) 3057.6, 2951.2, 2894.1, 1436.4, 1246.7, $1091.5,834.2,800.6,766.7 \mathrm{~cm}^{-1}$; MS $(70 \mathrm{eV}) \mathrm{m} / \mathrm{z} 368\left(\mathrm{M}^{+}\right)$; MS $m / z(\%) 368\left(\mathrm{M}^{+}, 0.1\right), 295(10), 243(5), 208(100), 164(12)$, 132(5), 73(38); HRMS $\left(\mathrm{M}^{+}\right)$calcd for $\mathrm{C}_{17} \mathrm{H}_{36} \mathrm{OSi}_{4} 368.1843$, found 368.1881 .

Irradiation of 2-(pentamethyldisilanyloxymethyl)phenylpentamethyldisilane 1 in methanol. A solution $\left(5 \times 10^{-4} \mathrm{M}\right)$ of 2-(pentamethyldisilanyloxymethyl)phenylpentamethyldisilane 1 (184 mg) in methanol (1 L) was deaerated by nitrogen purging for $1 \mathrm{~h}$ and irradiated in a Rayonet photochemical reactor, model RPR-208, equipped with RUL $254 \mathrm{~nm}$ lamps. After irradiation for $1 \mathrm{~min}$, the resulting photoreaction mixture was concentrated in vacuo. The photoproduct 3 was isolated in (95.2 $\mathrm{mg}, 80 \%$ yield) in addition to $2 \%(3.7 \mathrm{mg})$ of the starting material 1 by column chromatography with $n$-hexane/ethyl acetate $(20 / 1, v / v)$ as an eluent followed by normal phase HPLC using $n$-hexane/ethyl acetate $(10 / 1, \mathrm{v} / \mathrm{v})$ as an eluent. $3 ;{ }^{1} \mathrm{H}$ $\operatorname{NMR}\left(\mathrm{CDCl}_{3}, 300 \mathrm{MHz}\right) \delta_{\mathrm{H}} 0.09(9 \mathrm{H}, \mathrm{s}), 0.43(6 \mathrm{H}, \mathrm{s}), 1.90(1 \mathrm{H}$, s), $4.71(2 \mathrm{H}, \mathrm{s}), 7.30(1 \mathrm{H}, \mathrm{d}, J=7.2 \mathrm{~Hz}), 7.39(1 \mathrm{H}, \mathrm{td}, J=7.2$, $1.2 \mathrm{~Hz}), 7.49(2 \mathrm{H}, \mathrm{m}) ;{ }^{13} \mathrm{C} \mathrm{NMR}\left(\mathrm{CDCl}_{3}, 75 \mathrm{MHz}\right) \delta_{\mathrm{C}}-1.87$, $-1.51,65.9,127.3,127.8,129.4,135.1,137.6,146.4 ; \mathrm{UV}$ $\left(\mathrm{CH}_{2} \mathrm{Cl}_{2}\right) \lambda_{\max } 236 \mathrm{~nm}$; FT-IR $(\mathrm{NaCl}) 3325.2,3100.7,3024.7$, $2914.2,1558.0,1215.8,1110.8,858.5,816.5 \mathrm{~cm}^{-1}$; MS (70 
eV) $m / z 238\left(\mathrm{M}^{+}\right)$; MS m/z (\%) $238\left(\mathrm{M}^{+}, 6\right), 208(27), 179(28)$, 165(54), 147(100), 104(37), 83(23); HRMS $\left(\mathrm{M}^{+}\right)$calcd for $\mathrm{C}_{12} \mathrm{H}_{22} \mathrm{OSi}_{2} 238.1209$, found 238.1234.

Imadiation of 2-(pentamethyldisilanyloxymethyl)phenylpentamethyldisilane 1 in $\boldsymbol{n}$-hexane. A solution $\left(5 \times 10^{-4} \mathrm{M}\right)$ of 2-(pentamethyldisilanyloxymethyl)phenylpentamethyldisilane 1 (184 mg) in $n$-hexane ( $1 \mathrm{~L})$ was deaerated by nitrogen purging for $1 \mathrm{~h}$ and irradiated in a Rayonet photochemical reactor, model RPR-208, equipped with RUL $254 \mathrm{~nm}$ lamps. After irradiation for $40 \mathrm{~min}$, the resulting photoreaction mixture was concentrated in vacuo. The photoproduct $\mathbf{4}$ was isolated in $(104.9 \mathrm{mg}, 57 \%$ yield $)$ in addition to $15 \%(27.6 \mathrm{mg})$ of the starting material 1 by column chromatography with $n$-hexane/ethyl acetate $(70 / 1, \mathrm{v} / \mathrm{v})$ as an eluent followed by normal phase HPLC using $n$-hexane/ethyl acetate $(40 / 1, \mathrm{v} / \mathrm{v})$ as an eluent. 4; UV $\left(\mathrm{CH}_{2} \mathrm{Cl}_{2}\right) \lambda_{\max } 283,275 \mathrm{~nm}$; FT-IR (NaCl) 3056.1, 2952.9, $2894.9,1588.4,1434.5,1249.5,1049.3,833.7 \mathrm{~cm}^{-1}$; MS (70 eV) $m / z 368\left(\mathrm{M}^{+}\right)$; MS m/z (\%) $368\left(\mathrm{M}^{+}, 4\right), 339(5), 295(6)$, 281(17), 265(12), 221(16), 207(100), 191(13), 147(25), 130(15), 73(47); HRMS $\left(\mathrm{M}^{+}\right)$calcd for $\mathrm{C}_{17} \mathrm{H}_{36} \mathrm{OSi}_{4} 368.1843$, found 368.1892 .

\section{References}

1. Morkin, T. L.; Leigh, W. J. Acc. Chem. Res. 2001, 34, 129.

2. Ishikawa, M.; Shirai, S.; Naka, A.; Kobayashi, H.; Ohshita, J.; Kunai, A.; Yamamoto, Y.; Cha, S. H.; Lee, K. K.; Kwak, Y. W. Organometallics 2002, 21, 4206.

3. Naka, A.; Matsui, Y.; Kobayashi, H.; Ishikawa, M. Organometallics 2004, 23, 1509.

4. Naka, A.; Nakano, K.; Ishikawa, M.; Kwak, Y. W. J. Organomet. Chem. 2006, 691, 2440

5. Ishikawa, M.; Hatano, T.; Hasegawa, Y.; Horio, T.; Kunai, A.; Miyai, A.; Ishida, T.; Tsukihara, T.; Yamanaka, T.; Koike, T.; Shioya, J. Organometallics 1992, 11, 1604.

6. Ishikawa, M.; Ikadai, J.; Naka, A.; Ohshita, J.; Kunai, A.; Yoshizawa, K.; Kang, S. Y.; Yamabe, T. Organometallics 2001, 20, 1059.

7. Naka, A.; Ishikawa, M. Organometallics 2001, 20, 1695.

8. Naka, A.; Yoshida, K.; Ishikawa, M.; Miyahara, I.; Hirotsu, K.; Cha, S. H.; Lee, K. K.; Kwak, Y. W. Organometallics 2001, 20, 1204.

9. Yoshida, H.; Ikadai, J.; Shudo, M.; Ohshita, J.; Kunai, A. J. Am. Chem. Soc. 2003, 125, 6638 .

10. Naka, A.; Ikadai, J.; Sakata, J.; Miyahara, I.; Hirotsu, K.; Ishikawa, M. Organometallics 2004, 23, 2397.

11. Yoshida, H.; Ikadai, J.; Shudo, M.; Ohshita, J.; Kunai, A. Organometallics 2005, 24, 156.

12. Sun, H.; Pan, Y.; Huang, X.; Guo, Z.; Zhang, Z.; Zhang, H.; Li, J.; Wang, F. Organometallics 2006, 25, 133.

13. Kwak, Y. W.; Lee, I. S.; Baek, M. K.; Lee, U.; Choi, H. J.; Ishikawa, M.; Naka, A.; Ohshita, J.; Lee, K. H.; Kunai, A. Organometallics 2006, 25, 48.

14. Peindy, H. N.; Guyon, F.; Jourdain, I.; Knorr, M.; Schildbach, D.; Strohmann, C. Organometallics 2006, 25, 1472.

15. Sakurai, H.; Kumada, M. Bull. Chem. Soc. Jpn. 1964, 37, 1894. 16. Gilman, H.; Atwell, W. H.; Schwebke, G. J. Organomet. Chem.
1964, 2, 369.

17. Hague, D. N.; Prince, R. H. Chem. Ind. (London) 1964, 1492.

18. Shim, S. C.; Park, S. K. Tetrahedron Lett. 1998, 39, 6891.

19. Shim, S. C.; Park, S. K. Bull. Korean Chem. Soc. 1998, 19, 686.

20. Shim, S. C.; Park, S. K. Bull. Korean Chem. Soc. 1999, $20,547$.

21. Park, S. K.; Shim, S. C.; Seo, Y. W.; Shin, J. H. Tetrahedron Lett. 1999, 40, 4575.

22. Shim, S. C.; Park, S. K. J. Photosci. 1999, 6, 13.

23. Park, S. K.; Shim, S. C. J. Photochem. Photobiol. A: Chem. 2000, 136, 219.

24. Park, S. K. J. Photochem. Photobiol. A: Chem. 2001, 144, 167.

25. Park, S. K. Bull. Korean Chem. Soc. 2001, 22, 1202.

26. Park, S. K. J. Photosci. 2002, 9, 1.

27. Park, S. K.; Baek, D. J. J. Photochem. Photobiol. A: Chem. 2002, $150,125$.

28. Park, S. K.; Baek, D. J. J. Photochem. Photobiol. A: Chem. 2003, 157,15

29. Park, S. K.; Baek, D. J. J. Photochem. Photobiol. A: Chem. 2004, $163,87$.

30. Park, S. K. J. Photochem. Photobiol. A: Chem. 2005, 173, 29.

31. Park, S. K.; Seong, W. J. Bull. Korean Chem. Soc. 2009, 30, 1331.

32. Park, S. K. Bull. Korean Chem. Soc. 2008, 29, 1018.

33. Kira, M.; Miyazawa, T.; Sugiyama, H.; Yamaguchi, M.; Sakurai, H. J. Am. Chem. Soc. 1993, 115, 3116.

34. Nate, K.; Ishikawa, M.; Ni, H.; Watanabe, H.; Saheki, Y. Organometallics 1987, 6, 1673.

35. Ishikawa, M. Pure Appl. Chem. 1978, 50, 11.

36. Ishikawa, M.; Fuchikami, T.; Kumada, M. J. Organomet. Chem. 1976, 118, 139.

37. Ishikawa, M.; Fuchikami, T.; Kumada, M. J. Organomet. Chem. 1976, $118,155$.

38. Ishikawa, M.; Fuchikami, T.; Kumada, M. Tetrahedron Lett. 1976, 1299.

39. Ishikawa, M.; Fuchikami, T.; Kumada, M. J. Organomet. Chem. 1977, 133, 19.

40. Ishikawa, M.; Fuchikami, T.; Kumada, M. J. Organomet. Chem. 1978, 162, 223.

41. Ishikawa, M.; Oda, M.; Miyoshi, N.; Fabry, L.; Kumada, M.; Yamabe, T.; Akagi, K.; Fukui, K. J. Am. Chem. Soc. 1979, 101, 4612.

42. Ishikawa, M.; Oda, M.; Nishimura, K.; Kumada, M. Bull. Chem. Soc. Jpn. 1983, 56, 2795.

43. Takaki, K.; Sakamoto, H.; Nishimura, Y.; Sugihara, Y.; Ishikawa, M. Organometallics 1991, 10, 888 .

44. Ohshita, J.; Ohsaki, H.; Ishikawa, M.; Tachibana, A.; Kurosaki, Y.; Yamabe, T.; Tsukihara, T.; Takahashi, K.; Kiso, Y. Organometallics 1991, 10, 2685.

45. Ohshita, J.; Ohsaki, H.; Ishikawa, M. Organometallics 1991, 10, 2695.

46. Ishikawa, M.; Nishimura, Y.; Sakamoto, H. Organometallics 1991, $10,2701$.

47. Kira, M.; Sakamoto, K.; Sakurai, H. J. Am. Chem. Soc. 1983, 105, 7469.

48. Okinoshima, H.; Weber, W. P. J. Organomet. Chem. 1978, 149, 279.

49. Park, S. K. Bull. Korean Chem. Soc. 2007, 28, 1045.

50. Ishikawa, M.; Sakamoto, H.; Kanetani, F.; Minato, A. Organometallics 1989, 8, 2767.

51. Ohshita, J.; Ohsaki, H.; Ishikawa, M.; Tachibana, A.; Kurosaki, Y.; Yamabe, T.; Minato, A. Organometallics 1991, 10, 880.

52. Park, S. K. Bull. Korean Chem. Soc. 2006, 27, 1305. 